\title{
A Way to Improve Luminescent Efficiency of Bis-Chalcone Derivatives
}

\author{
Meng Guan Tay, ${ }^{1}$ Mee Hing Tiong, ${ }^{1}$ Ying Ying Chia, ${ }^{1}$ \\ Suzie Hui Chin Kuan, ${ }^{1}$ and Zhi-Qiang Liu ${ }^{2}$ \\ ${ }^{1}$ Department of Chemistry, Faculty of Resource Science and Technology, Universiti Malaysia Sarawak, \\ 94300 Kota Samarahan, Sarawak, Malaysia \\ ${ }^{2}$ State Key Laboratory of Crystal Materials, Shandong University, 27 Shanda South Road, Jinan 250100, China
}

Correspondence should be addressed to Meng Guan Tay; mgtay@unimas.my

Received 30 April 2016; Accepted 20 June 2016

Academic Editor: Artur M. S. Silva

Copyright (C) 2016 Meng Guan Tay et al. This is an open access article distributed under the Creative Commons Attribution License, which permits unrestricted use, distribution, and reproduction in any medium, provided the original work is properly cited.

Chalcone related compounds have been reported as a poor luminescence molecule due to the quenching processes from the intramolecular torsional motions and cis-trans isomerization in the $\alpha, \beta$-unsaturated ketone moiety. Despite this limitation, we found a way to improve the luminescent efficiency of our bis-chalcone derivative. In this project, two series of bischalcone compounds have been synthesized through Claisen-Schmidt condensation by reacting terephthaldehyde or 2,5-

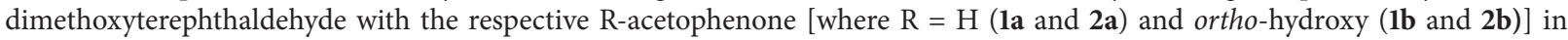
$1: 2$ mole ratio. The presence of a methoxy $(\mathrm{OMe})$ substituent on the central phenyl ring of bis-chalcone has weakened the $\mathrm{C}=\mathrm{C}$ bond at the $\alpha, \beta$-unsaturated ketone moiety of $\mathbf{2} \mathbf{a}$ and $\mathbf{2 b}$. Interestingly, the OMe group has improved the emission efficiency of the bis-chalcone; that is, the quantum yield of 1a in DCM solution was not able to be determined due to poor luminescence, but the quantum yield of 2a in DCM solution was improved to 0.57 . In addition, compound 2a also shows solvatochromism effect where the $\lambda_{\max }$ emission shifted from $499 \mathrm{~nm}$ in nonpolar solvents (benzene) to $523 \mathrm{~nm}$ in polar solvents (acetonitrile). This work provides another way to improve the emission efficiency of chalcone related compounds apart from using the complexation method which has been reported before.

\section{Introduction}

Chalcone and its derivatives have been known to exhibit antimicrobial, antitumor, anti-HIV, antimalarial, anti-inflammatory, and anticarcinogenic activities [1-6]. The $\alpha, \beta$ unsaturated ketone $(\mathrm{C}=\mathrm{C}-\mathrm{C}=\mathrm{O})$ moiety in the chalcone structure plays an important role in chalcone derivative compounds' biological activities. Selvi and coworkers (2012) found that most of these biological effects are related to the ability to create an electrophilic site that is then able to act as a binding site for biological targets [7].

Apart from the biological activities, the photophysical properties of chalcone derivatives also attracted considerable attention from both chemists and physicists. For example, chalcone derivatives have been reported in relation to nonlinear optics (NLO), photorefractive polymers, holographic recording materials, and fluorescent probes for the sensing of metal ions [8-14]. However, one of the main limitations in the photophysical properties of chalcones is their weak luminescent efficiency, which is due to quenching processes from the intramolecular torsional motions and cis-trans isomerization in the $\alpha, \beta$-unsaturated ketone moiety $[15,16]$.

Unlike the biological properties, the photophysical properties of chalcone derivatives such as $2^{\prime}$-hydroxychalcones have still not been fully understood. This could be the reason for limited use of chalcone derivatives and complexes in current green technology devices. D’Aléo and his coworkers (2012) found that the boron complexes with $2^{\prime}$-hydroxychalcone derivatives can increase the fluorescent efficiency from 0.02 to 0.79 by substituting different electron donor groups at the $2^{\prime}$-hydroxychalcone moiety [17]. Herein, we report two series of bis-chalcone derivatives (Scheme 1) in which the emission efficiency also showed dramatic improvement after addition of the methoxy $(\mathrm{OMe})$ moiety on the central 


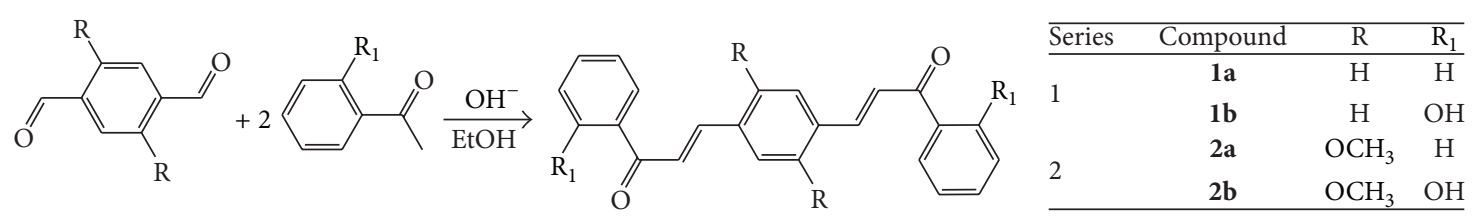

Scheme 1: Synthesis of bis-chalcones $\mathbf{1 a}-\mathbf{2} \mathbf{b}$.

phenyl ring. This work provides another way to improve the emission efficiency of chalcone related compounds apart from using the complexation method as reported by D'Aléo et al. (2012). Compounds $\mathbf{1 a}$ and $\mathbf{1 b}$ were reported by a number of researchers; however, the compounds were mainly used as a starting material for other compounds' synthesis and also were studied concerning their biological activities [18-25], yet, the photophysical properties of $\mathbf{l a}$ and $\mathbf{1 b}$ were not the main concern in these papers.

\section{Materials and Methods}

2.1. Characterizations. Melting point was measured using open capillary in Stuart MP3 melting point apparatus. UV-Vis spectra were recorded in dichloromethane (DCM) or dimethyl sulfoxide (DMSO) solution with a Jasco V630 ultraviolet spectrophotometer. Infrared spectra were recorded on $\mathrm{KBr}$ discs using Thermo Scientific Nicolet iS10 Fourier-Transform Infrared Spectrophotometer in the range of $4000-370 \mathrm{~cm}^{-1}$ at room temperature. The ${ }^{1} \mathrm{H}$ and ${ }^{13} \mathrm{C}$ NMR spectra were recorded on a JEOL $500 \mathrm{MHz}$-NMR spectrometer using DMSO- $d_{6}$ and $\mathrm{CDCl}_{3}$ which were set at 2.50 and $7.25 \mathrm{ppm}$ as standard reference of the solvent. Elemental analyses were performed using a Thermo Scientific FLASH 2000 HT Elemental Analyser operated by Eager 300 software.

$\mathrm{X}$-ray measurements for compound $\mathbf{1 b}$ were performed on a Bruker SMART diffractometer equipped with a graphite monochromated Mo Ka $(\lambda=0.71073)$ radiation source and a CCD detector. Frame integration was performed using the program SAINT [28]. The structure was resolved using a direct method provided by the program package SHELXTL97 and refined using full matrix least square against F2 for all data [29]. All nonhydrogen atoms were refined anisotropically. All hydrogen atoms were introduced at idealized positions and were allowed to refine isotropically.

2.2. Quantum Yield and Lifetime Measurements of Compound $2 \boldsymbol{a}$. The fluorescence quantum yield of $2 \mathbf{a}$ in DCM solution was measured using a calibrated integrating sphere (inner diameter: $150 \mathrm{~mm}$ ) from Edinburgh Instruments FLSP920 spectrometer. The lifetime of this compound was recorded in FLS980 spectrometer using time-correlated single-photon counting (TCSPC) method. The DCM solution of compound 2a was excited with pulsed laser diode at the wavelength of $376 \mathrm{~nm}$ in the lifetime measurement.

2.3. General Preparation Procedures of Bis-Chalcones $\mathbf{1 a}-\mathbf{2 b}$. $10 \mathrm{~mL}$ of $10 \% \mathrm{KOH}$ was added to a $125 \mathrm{~mL}$ conical flask that contained a solution of R-acetophenone (2 eq. mol) [where $\mathrm{R}=\mathrm{H}$ (1a and $\mathbf{2 a}$ ) and ortho- $\mathrm{OH}(\mathbf{1 b}$ and $\mathbf{2 b})]$ in $20 \mathrm{~mL}$ ethanol. The mixture was stirred for $5 \mathrm{~min}$ and added to $10 \mathrm{~mL}$ ethanolic solution of terephthaldehyde for the synthesis of bis-chalcones $\mathbf{1 a}$ and $\mathbf{1 b}(0.67 \mathrm{~g}, 5 \mathrm{mmol})$ or 2,5-dimethoxyterephthaldehyde for the synthesis of bischalcones $\mathbf{2} \mathbf{a}$ and $\mathbf{2} \mathbf{b}(0.20 \mathrm{~g}, 1 \mathrm{mmol})$. The mixture was stirred vigorously for $24 \mathrm{~h}$ at room temperature. Then, $\mathrm{HCl}(3.0 \mathrm{M})$ was added dropwise until the mixture solution was neutralized. The precipitated solid was filtered and then washed with ethanol and hot water and dried under reduced pressure. The solid was purified via recrystallization from the slow diffusion of hexane into the DCM solution.

3-[4-(3-Oxo-3-pheylpro-penpyl)-phenyl]-1-phenyl-propenone, $1 a$ [18-24, 30]. Yellow solid. Yield: 1.58 g, 93\%. M.P.: 193.7$195.4^{\circ} \mathrm{C} . \mathrm{IR}\left(\mathrm{KBr}, \mathrm{cm}^{-1}\right): 1655(\nu \mathrm{C}=\mathrm{O}), 1606(\nu \mathrm{C}=\mathrm{C}), 1579$ and $1445\left(v \mathrm{C}=\mathrm{C}\right.$, aromatic ring). ${ }^{1} \mathrm{H}-\mathrm{NMR}\left(500 \mathrm{MHz}, \mathrm{CDCl}_{3}\right) \delta$ : $8.02(\mathrm{~d}, 4 \mathrm{H}, J=8 \mathrm{~Hz}, \mathrm{Ar}-\mathrm{H}), 7.80\left(\mathrm{~d}, 2 \mathrm{H}, J=16 \mathrm{~Hz}, \mathrm{CH}=\mathrm{CH}_{\beta}\right.$, ), 7.68 (s, 4H, Ar-H), 7.59 (t, 2H, $J=6 \mathrm{~Hz}, \operatorname{Ar}-\mathrm{H}), 7.57$ (d, $\overline{2} \mathrm{H}$, $\left.J=16 \mathrm{~Hz}, \mathrm{CH}_{\alpha}=\mathrm{CH}\right), 7.51(\mathrm{t}, 4 \mathrm{H}, J=7 \mathrm{~Hz}, \mathrm{Ar}-\mathrm{H}), 6.96(\mathrm{t}$, $2 \mathrm{H}, J=7 \mathrm{~Hz}, \overline{\mathrm{Ar}}-\mathrm{H}) .{ }^{13} \mathrm{C}-\mathrm{NMR}\left(125 \mathrm{MHz}, \mathrm{CDCl}_{3}\right) \delta: 189.9$, $143.5,138.0,136.8,133.0,129.0,128.7,128.5$ and 123.0. UV-Vis (DCM) $\left(\lambda_{\max } / \mathrm{nm}\right): 270$ and 348. Anal. Cal. for $\mathrm{C}_{24} \mathrm{H}_{18} \mathrm{O}_{2}: \mathrm{C}$, 85.18; H, 5.36; Found: C, 85.23; H, 5.37.

1-(2-Hydroxyphenyl)-3-\{4-[3-(2-hydroxyphenyl)-3-oxo-propenyl]-phenyl\}-propenone, $\mathbf{1 b}[25,30]$. Yellow solid. Yield: 1.45 g, $80 \%$. M.P.: $235.4-236.9^{\circ} \mathrm{C}$. IR $\left(\mathrm{KBr}, \mathrm{cm}^{-1}\right): 3450(v \mathrm{OH})$, $1638(v \mathrm{C}=\mathrm{O}), 1606(v \mathrm{C}=\mathrm{C}), 1567$ and $1486(v \mathrm{C}=\mathrm{C}$, aromatic ring). ${ }^{1} \mathrm{H}-\mathrm{NMR}\left(500 \mathrm{MHz}, \mathrm{CDCl}_{3}\right) \delta: 12.74(\mathrm{~s}, 2 \mathrm{H}, \mathrm{OH}), 7.93$ $(\mathrm{d}, 2 \mathrm{H}, J=8 \mathrm{~Hz}, \mathrm{Ar}-\mathrm{H}), 7.92\left(\mathrm{~d}, 2 \mathrm{H}, J=15 \mathrm{~Hz}, \mathrm{CH}=\mathrm{CH}_{\beta}\right), 7.73$ (s, $4 \mathrm{H}, \operatorname{Ar}-\mathrm{H}), 7.71\left(\mathrm{~d}, 2 \mathrm{H}, J=15 \mathrm{~Hz}, \mathrm{CH}_{\alpha}=\mathrm{CH}\right), 7.51(\mathrm{t}, 2 \mathrm{H}$, $J=6 \mathrm{~Hz}, \mathrm{Ar}-\mathrm{H}), 7.04$ (d, 2H, $J=8 \mathrm{~Hz}, \mathrm{Ar}-\mathrm{H}), 6.97$ (t, 2H, $J=$ $7 \mathrm{~Hz}, \mathrm{Ar}-\mathrm{H}) .{ }^{13} \mathrm{C}-\mathrm{NMR}\left(125 \mathrm{MHz}, \mathrm{DMSO}-d_{6}\right) \delta: 193.5,143.5$, $161.8,143.7,136.7,136.4,130.9,129.7,123.0,120.8,119.2$ and 117.8. UV-Vis (DCM) $\left(\lambda_{\max } / \mathrm{nm}\right): 285$ and 383. Anal. Cal. for $\mathrm{C}_{24} \mathrm{H}_{18} \mathrm{O}_{4}$ : C, 77.82; H, 4.90; Found: C, 77.85; H, 4.73.

3-[4-(3-Oxo-3-pheylpropenpyl)-phenyl]-2,5-dimethoxyphenylpropenone, $2 a$. Yellowish green solid. Yield: 0.36 g, $80 \%$. M.P.: 242.1-243.8 $8^{\circ}$. IR $\left(\mathrm{KBr}, \mathrm{cm}^{-1}\right): 1639(v \mathrm{C}=\mathrm{O}), 1577(v \mathrm{C}=\mathrm{C})$, $1564 \& 1484(v \mathrm{C}=\mathrm{C}$, aromatic ring $), 1180\left(v \mathrm{OCH}_{3}\right) .{ }^{1} \mathrm{H}-\mathrm{NMR}$ $\left(500 \mathrm{MHz}, \mathrm{DMSO}-d_{6}\right) \delta: 8.06\left(\mathrm{~d}, 2 \mathrm{H}, J=16 \mathrm{~Hz}, \mathrm{CH}=\mathrm{CH}_{\beta}\right)$, $8.03(\mathrm{~d}, 4 \mathrm{H}, J=7 \mathrm{~Hz}, \mathrm{Ar}-\mathrm{H}), 7.72$ (s, 2H, Ar-H), 7.67 (d, 2H, $\bar{J}=$ $\left.16 \mathrm{~Hz}, \mathrm{CH}_{\alpha}=\mathrm{CH}\right), 7.60(\mathrm{t}, 4 \mathrm{H}, J=8 \mathrm{~Hz}, \mathrm{Ar}-\mathrm{H}), 7.53(\mathrm{t}, 2 \mathrm{H}, J=$ $8 \mathrm{~Hz}, \mathrm{Ar}-\overline{\mathrm{H}}), 7.16$ (d, 2H, $J=8 \mathrm{~Hz}, \mathrm{Ar}-\mathrm{H}), 3.96$ (s, $6 \mathrm{H}, \mathrm{OCH}_{3}$ ). ${ }^{13} \mathrm{C}-\mathrm{NMR}\left(125 \mathrm{MHz}, \mathrm{DMSO}-d_{6}\right) \delta: 189.9,152.8,138.1,133.3$, $129.4,129.0,127.1,123.7,111.7,110.6$ and 57.3. UV-Vis (DCM) $\left(\lambda_{\max } / \mathrm{nm}\right): 268,333$ and 421 . Anal. Cal. for $\mathrm{C}_{26} \mathrm{H}_{22} \mathrm{O}_{4}: \mathrm{C}$, 78.37; H, 5.57; Found: C, 77.75; H, 5.54. 


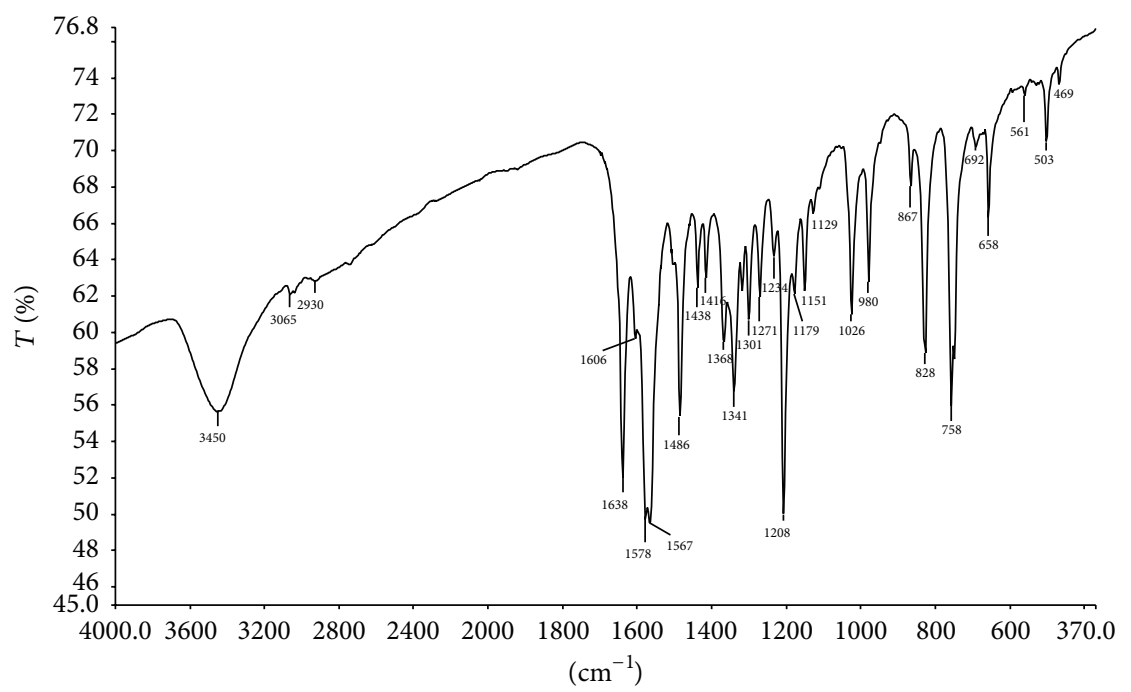

FIGURE 1: IR spectrum of compound $\mathbf{l b}$.

1-(2-Hydroxyphenyl)-3-\{4-[3-(2-hydroxyphenyl)-3-oxo-propenyl]-2,5-dimethoxyphenyl\}-propenone, $\mathbf{2 b}$. Orange solid. Yield: 0.36 g, $76 \%$. M.P.: $252.6-253.4^{\circ} \mathrm{C}$. IR $\left(\mathrm{KBr}, \mathrm{cm}^{-1}\right): 3449$ $(v \mathrm{OH}), 1633(v \mathrm{C}=\mathrm{O}), 1578(v \mathrm{C}=\mathrm{C}), 1561$ and $1489(v \mathrm{C}=\mathrm{C}$, aromatic ring), $1197\left(v \mathrm{OCH}_{3}\right) .{ }^{1} \mathrm{H}-\mathrm{NMR}\left(500 \mathrm{MHz}, \mathrm{CDCl}_{3}\right)$ $\delta: 12.74(\mathrm{~s}, 2 \mathrm{H}, \mathrm{OH}), 7.93(\mathrm{~d}, 2 \mathrm{H}, J=8 \mathrm{~Hz}, \operatorname{Ar}-\mathrm{H}), 7.92(\mathrm{~d}, 2 \mathrm{H}$, $\left.J=15 \mathrm{~Hz}, \mathrm{CH}=\mathrm{CH}_{\beta}\right), 7.73(\mathrm{~s}, 2 \mathrm{H}, \mathrm{Ar}-\mathrm{H}), 7.71(\mathrm{~d}, 2 \mathrm{H}, J=15 \mathrm{~Hz}$, $\left.\mathrm{CH}_{\underline{\alpha}}=\mathrm{CH}\right), 7.51(\mathrm{t}, \overline{2} \mathrm{H}, J=6 \mathrm{~Hz}, \mathrm{Ar}-\mathrm{H}), 7.04(\mathrm{~d}, 2 \mathrm{H}, J=8 \mathrm{~Hz}$, Ar- -6$), 66$ (t, 2H, $J=6 \mathrm{~Hz}$, Ar-H). ${ }^{13} \mathrm{C}-\mathrm{NMR}(125 \mathrm{MHz}$, $\left.\mathrm{CDCl}_{3}\right) \delta: 194.1,163.6,153.4,140.1,136.4,129.7,126.6,122.4$, $120.2,118.8,118.6,112.2$ and 56.3. UV-Vis (DCM) $\left(\lambda_{\max } / \mathrm{nm}\right)$ : 275, 350 and 445. Anal. Cal. for $\mathrm{C}_{26} \mathrm{H}_{22} \mathrm{O}_{6}$ : C, 72.55; H, 5.15; Found: C, 71.79; H, 4.95.

\section{Results and Discussion}

3.1. Spectroscopic Analyses. The formation of bis-chalcones can be represented by the presence of $\alpha, \beta$-unsaturated ketone $(\mathrm{C}=\mathrm{C}-\mathrm{C}=\mathrm{O})$ bands at $1633-1665 \mathrm{~cm}^{-1}$ for $\mathrm{C}=\mathrm{O}$ and $1577-$ $1606 \mathrm{~cm}^{-1}$ for $\mathrm{C}=\mathrm{C}$ in the IR spectra. The IR frequency of $\mathrm{C}=\mathrm{O}$ group is lower than the typical value $\left(\mathrm{ca} .1700 \mathrm{~cm}^{-1}\right)$ because of the conjugation effect along the $\mathrm{C}=\mathrm{C}-\mathrm{C}=\mathrm{O}$ moiety. The presence of the electron donor and acceptor at the paraand ortho-positions of the wing phenyl rings shifted the energy of the carbonyl group and $\mathrm{C}=\mathrm{C}$ aliphatic group. For example, for bis-chalcone $1 \mathrm{a}$, the $\mathrm{C}=\mathrm{O}$ band was present at the frequency of $1655 \mathrm{~cm}^{-1}$, but a lower frequency of $\mathrm{C}=\mathrm{O}$ band (ca. $1638 \mathrm{~cm}^{-1}$ ) was observed in bis-chalcone $\mathbf{1 b}$, which has ortho- $\mathrm{OH}$ as the substituent (Figure 1). In addition, the presence of methoxy (OMe) substituent on the central phenyl ring also shifts the IR frequency of $\mathrm{C}=\mathrm{C}$ in bis-chalcones 2a and $2 \mathbf{b}\left(1583-1578 \mathrm{~cm}^{-1}\right)$ to a lower frequency compared to compounds $\mathbf{l a}$ and $\mathbf{1 b}\left(1606 \mathrm{~cm}^{-1}\right)$. This is due to the electron donation from $\mathrm{OCH}_{3}$ group to the $\mathrm{C}=\mathrm{C}$ aliphatic moiety which consequently weakens the $\mathrm{C}=\mathrm{C}$ bond.

The $\mathrm{H}_{\alpha}$ and $\mathrm{H}_{\beta}$ protons of bis-chalcone appear as two doublets in the ranges of 7.6-8.2 ppm $\left(\mathrm{H}_{\alpha}\right)$ and 7.5-7.8 ppm
$\left(\mathrm{H}_{\beta}\right)$ with the coupling constant $(J)$ value of $15-16 \mathrm{~Hz}$ (Figure 2 ). The large $J$ value of these two protons clearly indicates that compounds $\mathbf{1 a}-\mathbf{2} \mathbf{b}$ are in the trans-conformation. For the ${ }^{13} \mathrm{C}-\mathrm{NMR}$ spectrum, the carbonyl carbon $(\mathrm{C}=\mathrm{O})$ of the bischalcones usually appears at the region of 189.9 to $194.1 \mathrm{ppm}$. The presence of $2^{\prime}$-hydroxyl group at the wing phenyl rings shifted the carbon resonance of $\mathrm{C}=\mathrm{O}$ from $190 \mathrm{ppm}$ for compound 2a downfield by $4 \mathrm{ppm}$ at $194 \mathrm{ppm}$ for compound 2b. This is due to the formation of hydrogen bond in between the $2^{\prime}$-hydroxyl and oxygen in the carbonyl groups.

3.2. X-Ray Crystallography of Bis-Chalcone 1b. The molecular structure of bis-chalcone $\mathbf{1 b}$ was previously reported by Gaur and Mishra in 2013 [25]. The yellow crystal of bis-chalcone $\mathbf{l b}$ was grown in DCM solution via slow diffusion in hexane under ambient conditions. The molecular structure of bischalcone $\mathbf{1 b}$ is shown in Figure 3 and the main crystallographic parameters are presented in Table 1. Bis-chalcone $\mathbf{1 b}$ crystallized into monoclinic crystal system with the space group of $P 2_{1} / n$. The bond length of C6-C7 is about $1.325 \AA$, which is close to the typical $\mathrm{C}=\mathrm{C}$ bond $(1.34 \AA)$. The single bonds of C4-C5, C5-C6, and C7-C8 are in the range of $1.459-1.467 \AA$, which is relatively shorter than the typical single bond (1.54 $\AA$ ). This is due to the fact of the conjugated system present along the molecule [31]. On the other hand, supporting the discussion of the ${ }^{13} \mathrm{C}-\mathrm{NMR}$ above, the molecular structure of bis-chalcone $\mathbf{l b}$ shows the presence of intramolecular hydrogen bond in between phenolic hydrogen and the oxygen atom at $\mathrm{C}=\mathrm{O}$.

3.3. Photophysical Studies on Bis-Chalcone Compounds. The photophysical data of bis-chalcones $\mathbf{1 a - 2} \mathbf{b}$ are shown in Table 2, and the absorption spectra of bis-chalcones 1a and 2a in DCM are shown in Figure 4.

Two absorption bands located at $268-278 \mathrm{~nm}$ and $333-$ $383 \mathrm{~nm}$ were observed in bis-chalcones $\mathbf{1 a}-\mathbf{2} \mathbf{b}$; however, for bis-chalcones $\mathbf{2} \mathbf{a}-\mathbf{2} \mathbf{b}$, an additional absorption band was observed at about $421 \mathrm{~nm}$, which corresponded to 


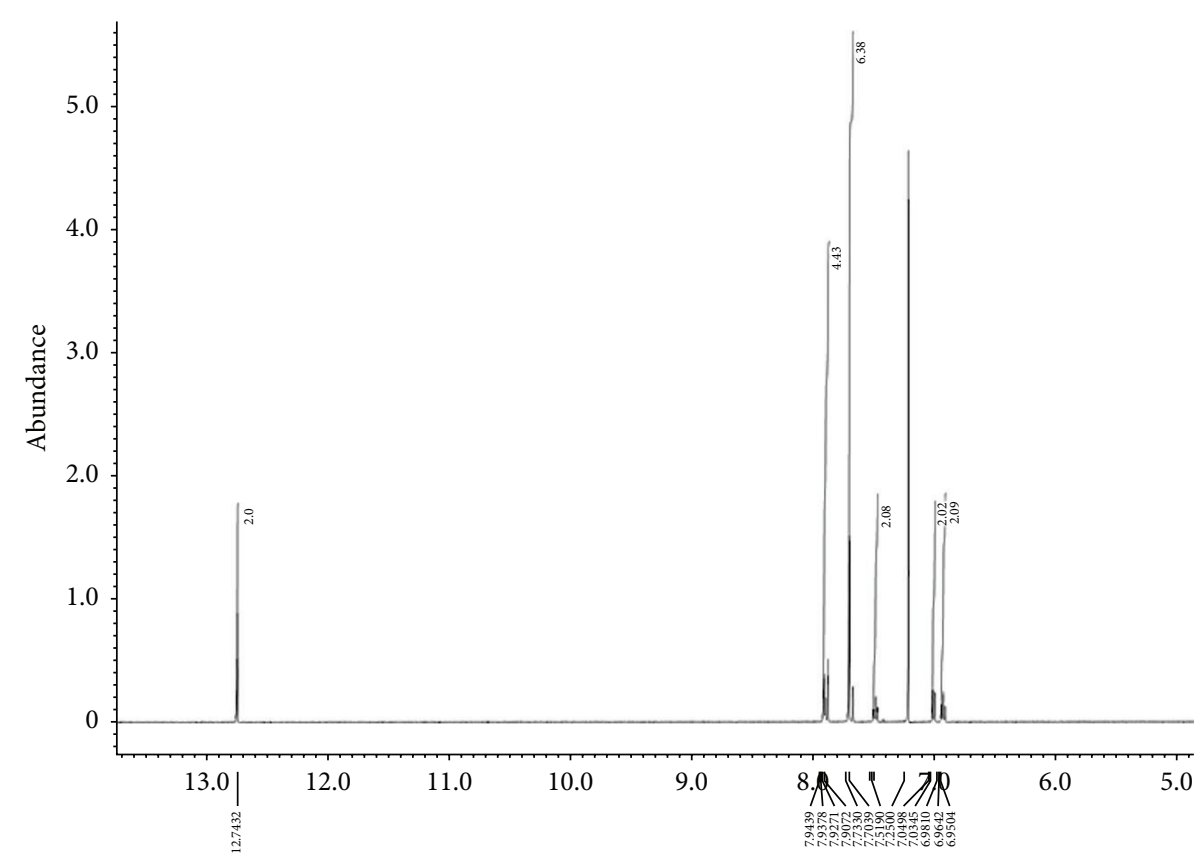

FIGURE 2: ${ }^{1} \mathrm{H}$ NMR spectrum of compound $\mathbf{l b}$.

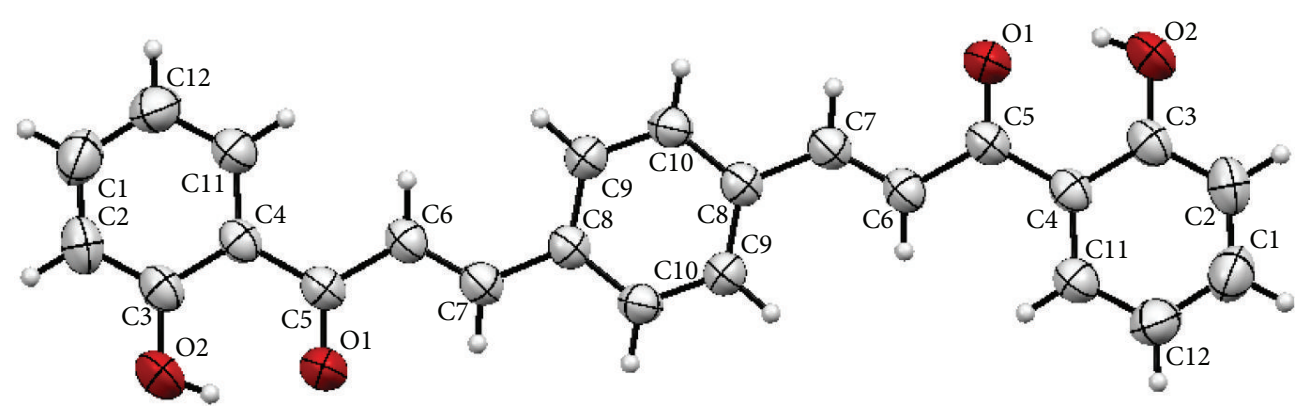

FIgURE 3: Molecular structure of bis-chalcone $\mathbf{1 b}$ with the thermal ellipsoids plotted at $50 \%$ probability.

intramolecular charge transfer (ICT) from an ethylenic $\pi$ electron to a carbonyl $\pi$ electron [31,32]. The absorption band at the range of 268 to $278 \mathrm{~nm}$ corresponded to the $\pi \rightarrow \pi^{*}$ transition in the aromatic ring. The absorption of this transition normally appears at around $200-250 \mathrm{~nm}$; however, due to the conjugation effect of the carbonyl group and the carbon-carbon double bond system with the aromatic ring, the $\pi \rightarrow \pi^{*}$ transition was shifted to a longer wavelength. The presence of ortho-hydroxyl group at the wing phenyl rings has shifted the $\pi \rightarrow \pi^{*}$ and $n \rightarrow \pi^{*}$ transitions in compounds $\mathbf{1 b}$ and $\mathbf{2 b}$ to a lower energy region (a longer wavelength). This is because the electron donating nature of the hydroxyl group has weakened the bond order of $\mathrm{C}=\mathrm{C}$ and $\mathrm{C}=\mathrm{O}$ groups. Surprisingly, the $n \rightarrow \pi^{*}$ transition $(\varepsilon=\mathrm{ca}$. $\left.22,000-26,000 \mathrm{~mol}^{-1} \mathrm{~cm}^{-1} \mathrm{dm}^{3}\right)$ is much stronger than the $\pi \rightarrow \pi^{*}$ transition (ca. 9,700-15,000 $\mathrm{mol}^{-1} \mathrm{~cm}^{-1} \mathrm{dm}^{3}$ ) in all the reported bis-chalcone compounds. This phenomenon can be explained by the presence of extended conjugation $\mathrm{C}=\mathrm{C}$ $\mathrm{C}=\mathrm{O}$ chromophoric system in the bis-chalcone structure, which resulted in greater delocalization of $\pi$ electrons along the molecule [31]. Similar phenomena of absorption spectra were also found in the papers reported by $\mathrm{Si}$ and his coworkers in 2011 [13] and Tay et al. [33]. In the bis-chalcones reported by $\mathrm{Si}$ et al., they claimed that the increase of the absorption band $259 \mathrm{~nm}$ and the decrease of the band at $341 \mathrm{~nm}$ resulted from the $[2 \pi+2 \pi]$ cycloaddition of the double bond in the chalcone unit to give a cyclobutane ring [13].

The emission spectra of bis-chalcones $\mathbf{1 a}-\mathbf{1} \mathbf{b}$ and $\mathbf{2 a - 2} \mathbf{b}$ are shown in Figure 5. The emissions $\lambda_{\max }$ of bis-chalcones 2a and $\mathbf{2 b}$ were shifted to a lower energy after the addition of the OMe group on the central phenyl ring. In general, bischalcone compounds $\mathbf{1 a}, \mathbf{1} \mathbf{b}$, and $\mathbf{2} \mathbf{b}$ exhibited weak emission as seen in the low signal versus noise emission spectra. Due to this reason, we could not obtain the quantum yields and lifetimes of these compounds even in less polar solvents, that is, DCM. The quenching process in chalcones is normally due to intramolecular torsional motions as well as the cis-trans isomerization of the $\alpha, \beta$-unsaturated ketone moiety $[15,16]$. However, for compounds $\mathbf{1 b}$ and $\mathbf{2} \mathbf{b}$, quenching could also 

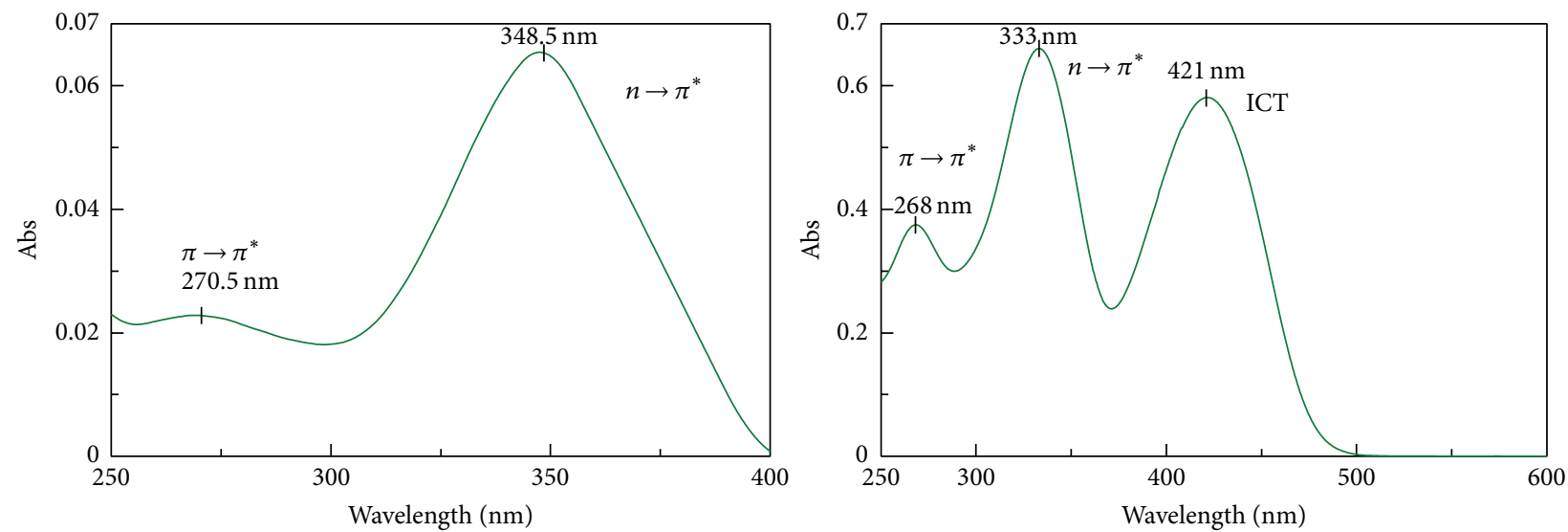

FIgURE 4: Absorption spectrum of bis-chalcones 1a (top) and 2a (bottom) in DCM.

TABLE 1: Summary of crystal data and structure refinement parameters of bis-chalcone $\mathbf{1 b}$.

\begin{tabular}{lc}
\hline Compound & $\mathbf{1 b}$ \\
\hline Empirical formula & $\mathrm{C}_{24} \mathrm{H}_{18} \mathrm{O}_{4}$ \\
Formula weight & 370.38 \\
Temperature $(\mathrm{K})$ & $296(2)$ \\
Crystal system & Monoclinic \\
Space group & $P 2_{1} / n$ \\
$a(\AA)$ & $4.9841(10)$ \\
$b(\AA)$ & $27.0759(7)$ \\
$c(\AA)$ & $6.9770(2)$ \\
$\alpha\left(^{\circ}\right)$ & 90.00 \\
$\beta\left(^{\circ}\right)$ & $101.37(2)$ \\
$\gamma\left({ }^{\circ}\right)$ & 90.00 \\
Volume $\left(\AA^{3}\right)$ & $923.05(4)$ \\
$Z$ & 2 \\
Density (calculated) $\left(\mathrm{mg} / \mathrm{m}^{3}\right)$ & 1.333 \\
Absorption coefficient $\left(\mathrm{mm}^{-1}\right)$ & 0.090 \\
$\Theta$ range for data collection $\left(^{\circ}\right)$ & 3.07 to 25.87 \\
Reflections collected & 2111 \\
Independent reflections & 1546 \\
Data/restraints/parameters & $2111 / 0 / 129$ \\
Final $R$ indices $[I>2 \sigma(I)]$ & $R 1=0.0394$ \\
$R$ indices $($ all data $)$ & $w R 2=0.1164$ \\
& $R 1=0.0565$ \\
& $w R 2=0.1326$ \\
\hline
\end{tabular}

be due to the intramolecular hydrogen bond, which can be observed from the molecular structure of $\mathbf{1 b}$ in Figure 3.

Interestingly, bis-chalcone $\mathbf{2 a}$ was found to be highly emissive at $505 \mathrm{~nm}$ with a quantum yield of 0.57 as well as lifetimes of 2.44 and 4.04 ns in DCM solution. Apart from DCM, this compound also shows intense emission in polar solvents, that is, acetonitrile. The quantum yield in acetonitrile was 0.40 using Coumarin 307 as the reference [26, 27]. The nanosecond lifetime indicates that emission originates from the singlet excited state. Comparing bis-chalcone la, the emission efficiency of bis-chalcone 2 a improves when there is an OMe group on the central phenyl ring. Chalcone and related compounds are generally known as poor emitters. The introduction of an OMe group on the central phenyl ring in compound $2 \mathbf{a}$ is considered another method to improve the emission efficiency of chalcone compounds apart from the method reported by D'Aléo and his coworkers (2012) [17].

3.4. Solvatochromism Study of Bis-Chalcone 2a. The solvatochromism study of bis-chalcone $\mathbf{2 a}$ was performed by dissolving the compound in the following solvents: benzene, tetrahydrofuran (THF), DCM, and acetonitrile (MeCN). The emission $\lambda_{\max }$ changed from $499 \mathrm{~nm}$ (blue) in benzene to $523 \mathrm{~nm}$ (yellowish green) in MeCN (Figure 6), which indicates that the excited molecule of bis-chalcone $2 \mathbf{a}$ has intermolecular interaction with the polar solvent molecules. It is believed that intramolecular charge transfer occurred from the OMe group on the central phenyl ring towards both sides of the phenyl rings.

\section{Conclusions}

A method to improve the emission efficiency of bis-chalcone has been found. By adding a methoxy group at the central phenyl ring of bis-chalcone, the quantum yield of bischalcone 2a was improved to 0.57 in DCM solution, and it was still emissive $\left(\Phi_{F}=0.40\right)$ in acetonitrile using Coumarin 307 as the reference. A solvatochromism study of bis-chalcone 2a was performed and the emission $\lambda_{\text {max }}$ increased from $499 \mathrm{~nm}$ in benzene to $523 \mathrm{~nm}$ in MeCN.

\section{Competing Interests}

The authors declare that they have no competing interests.

\section{Acknowledgments}

The authors wish to thank the Ministry of Higher Education, Malaysia, for the Fundamental Research Grant Scheme [FRGS/SG01(01)/1067/2013(13)] for the financial support of 
TABLE 2: Photophysical data for compounds $\mathbf{1 a}$ to $\mathbf{2} \mathbf{b}$ in solution state at room temperature.

\begin{tabular}{|c|c|c|c|c|c|}
\hline Compound & $\lambda_{\mathrm{abs}}{ }^{\mathrm{a}} / \mathrm{nm}\left(\varepsilon / 10^{4} \mathrm{M}^{-1} \mathrm{~cm}^{-1}\right)$ & $\lambda_{\mathrm{em}} / \mathrm{nm}$ & $\Phi_{F}$ & $\tau_{F} / \mathrm{ns}$ & Stokes shift $/ \mathrm{cm}^{-1}$ \\
\hline \multirow{2}{*}{ la } & $270(0.970)$ & $\sim 430$ & $-^{\mathrm{b}}$ & $-^{\mathrm{b}}$ & 5500 \\
\hline & $348(2.228)$ & & & & \\
\hline \multirow{2}{*}{$1 \mathbf{b}$} & $278(0.979)$ & $\sim 432$ & $-^{\mathrm{b}}$ & $-^{\mathrm{b}}$ & 3000 \\
\hline & $383(2.369)$ & & & & \\
\hline \multirow{3}{*}{$2 \mathbf{a}$} & $268(1.519)$ & 505 & $0.57^{\mathrm{c}}$ & $2.44(15 \%)$ & 10200 \\
\hline & $333(2.662)$ & & $0.40^{\mathrm{d}}$ & $4.04(85 \%)$ & \\
\hline & $421(2.384)$ & & & & \\
\hline \multirow{3}{*}{$2 b$} & $275(1.385)$ & $-{ }^{b}$ & $-^{\mathrm{b}}$ & $-^{\mathrm{b}}$ & - \\
\hline & $350(2.164)$ & & & & \\
\hline & $445(2.576)$ & & & & \\
\hline
\end{tabular}

${ }^{a}$ All the UV data was recorded in DCM solution. ${ }^{b}$ Not able to be determined due to very poor emission. ${ }^{c}$ Fluorescence quantum yield which was measured in DCM solution using an integrating sphere. ${ }^{\mathrm{d}}$ Fluorescence quantum yield which was measured in acetonitrile solution using Coumarin 307 as a reference $[26,27] .{ }^{\mathrm{e}}$ Stokes shift was calculated based on $\lambda_{\max }$ abs $-\lambda_{\max } \mathrm{em}$.

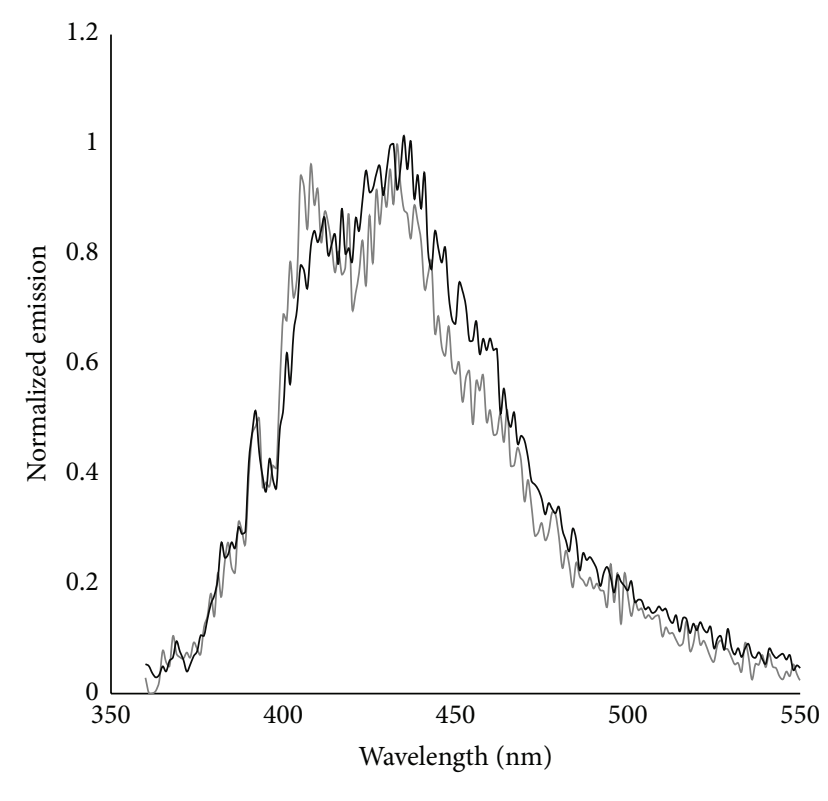

$1 \mathrm{a}$
$-1 \mathrm{~b}$

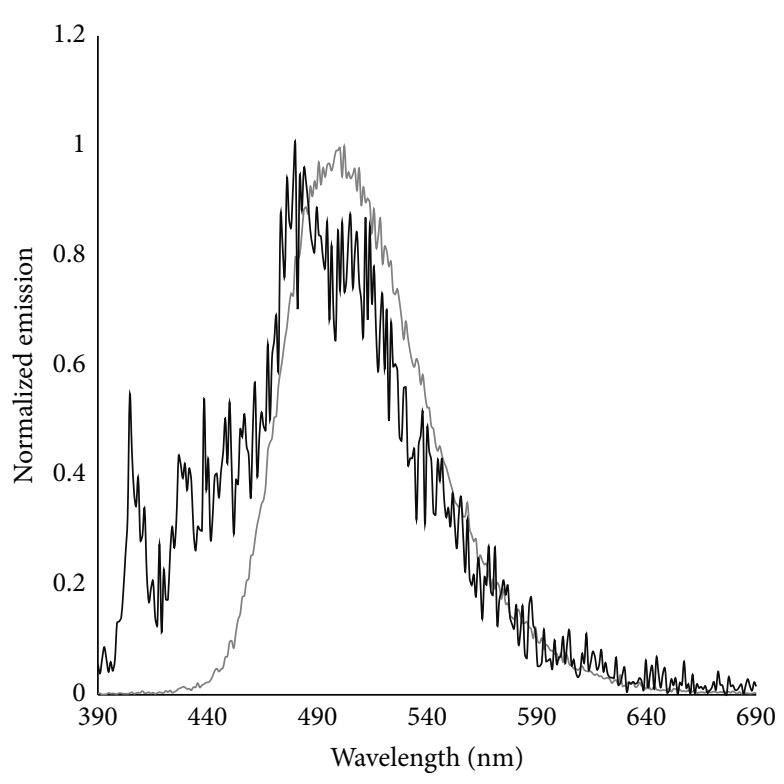

- 2a

FIgURE 5: Emission spectra of compounds 1a-1b (top) and 2a-2b (bottom) in DMSO.
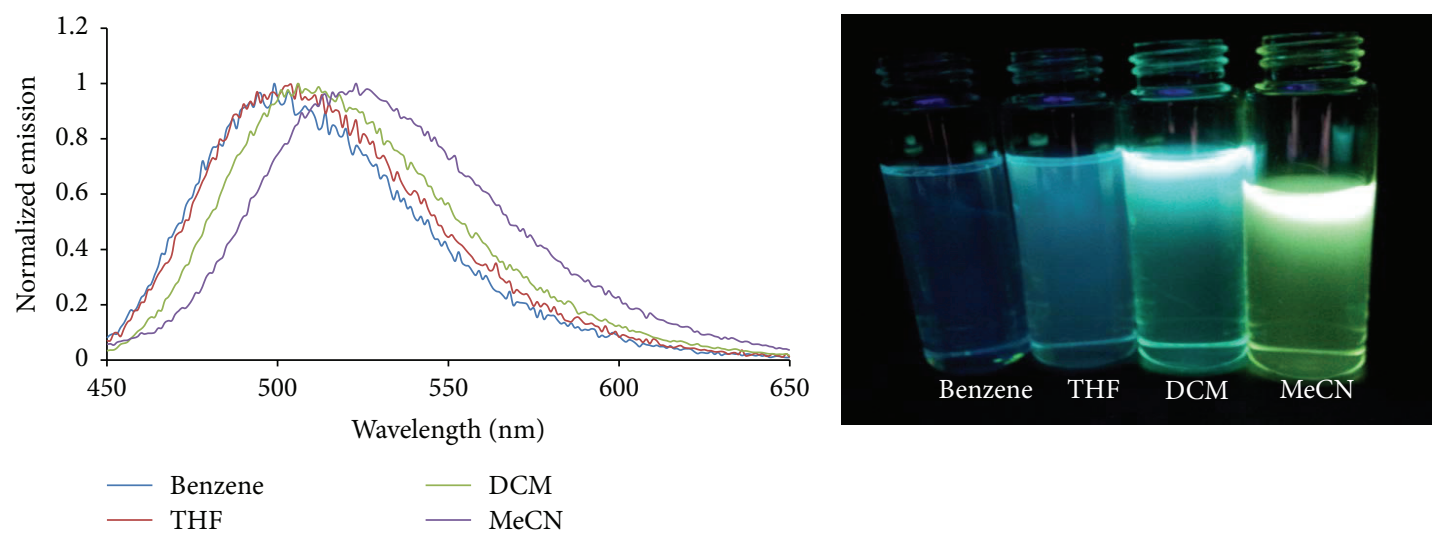

Figure 6: Solvatochromism study of bis-chalcone 2a. 
this work. Mee Hing Tiong thanks the funding from MyBrain 15 Program for supporting his Master Scholarship. Meng Guan Tay and Ying Ying Chia would like to thank Jörn Nitsch from the Julius-Maximilians-Universität Würzburg for his help in measuring the quantum yield and lifetime of $2 \mathbf{a}$. Last but not least, the authors also would like to thank Dr. Andrew Crawford for proofreading this paper.

\section{References}

[1] G. Achanta, A. Modzelewska, L. Feng, S. R. Khan, and P. Huang, "A boronic-chalcone derivative exhibits potent anticancer activity through inhibition of the proteasome," Molecular Pharmacology, vol. 70, no. 1, pp. 426-433, 2006.

[2] L. F. Motta, A. C. Gaudio, and Y. Takahata, "Quantitative structure-activity relationships of a series of chalcone derivatives (1,3-Diphenyl-2-propen-1-one) as nnti Plasmodium falciparum agents (anti-Malaria agents)," Internet Electronic Journal of Molecular Design, vol. 5, no. 12, pp. 555-569, 2006.

[3] Y. R. Prasad, A. Lakshmana Rao, and R. Rambabu, "Synthesis and antimicrobial activity of some chalcone derivatives," $E$ Journal of Chemistry, vol. 5, no. 3, pp. 461-466, 2008.

[4] N. M. Bhatia, K. R. Mahadik, and M. S. Bhatia, "QSAR analysis of 1,3-diaryl-2-propen-1-ones and their indole analogs for designing potent antibacterial agents," Chemical Papers, vol. 63, no. 4, pp. 456-463, 2009.

[5] A.-M. Katsori and D. Hadjipavlou-Litina, "Chalcones in cancer: understanding their role in terms of QSAR," Current Medicinal Chemistry, vol. 16, no. 9, pp. 1062-1081, 2009.

[6] X.-W. Zhang, D.-H. Zhao, Y.-C. Quan, L.-P. Sun, X.-M. Yin, and L.-P. Guan, "Synthesis and evaluation of antiinflammatory activity of substituted chalcone derivatives," Medicinal Chemistry Research, vol. 19, no. 4, pp. 403-412, 2010.

[7] R. S. Selvi, R. Nanthini, and G. Sukanyaa, "Synthesis, characterization and antimicrobial activity of certain chalcone based random copolyesters," Journal of Chemical and Pharmaceutical Research, vol. 4, no. 1, pp. 393-397, 2012.

[8] P. S. Patil, S. M. Dharmaprakash, K. Ramakrishna, H.-K. Fun, R. S. S. Kumar, and D. N. Rao, "Second harmonic generation and crystal growth of new chalcone derivatives," Journal of Crystal Growth, vol. 303, no. 2, pp. 520-524, 2007.

[9] H. Reyes, M. C. García, B. M. Flores, H. López-Rebolledo, R. Santillán, and N. Farfán, "Synthesis, NMR and X-ray diffraction analysis of boron complexes derived from hydroxychalcones," Journal of Mexico Chemical Society, vol. 50, no. 3, pp. 106-113, 2006.

[10] K. Rurack, J. L. Bricks, G. Reck, R. Radeglia, and U. ReschGenger, "Chalcone-analogue dyes emitting in the near-infrared (NIR): influence of donor-acceptor substitution and cation complexation on their spectroscopic properties and X-ray structure," The Journal of Physical Chemistry A, vol. 104, no. 14, pp. 3087-3109, 2000.

[11] C. Ruzié, M. Krayer, and J. S. Lindsey, "Fast and robust route to hydroporphyrin-chalcones with extended red or near-infrared absorption," Organic Letters, vol. 11, no. 8, pp. 1761-1764, 2009.

[12] T. A. Fayed, "A novel chalcone-analogue as an optical sensor based on ground and excited states intramolecular charge transfer: a combined experimental and theoretical study," Chemical Physics, vol. 324, no. 2-3, pp. 631-638, 2006.

[13] Z. K. Si, Q. Zhang, M. Z. Xue, Q. R. Sheng, and Y. G. Liu, "Novel UV-sensitive bis-chalcone derivatives: synthesis and photocrosslinking properties in solution and solid PMMA film,"
Research on Chemical Intermediates, vol. 37, no. 6, pp. 635-646, 2011.

[14] Y. Wei, G. Qin, W. Wang, W. Bian, S. Shuang, and C. Dong, "Development of fluorescent FeIII sensor based on chalcone," Journal of Luminescence, vol. 131, no. 8, pp. 1672-1676, 2011.

[15] T. A. Fayed and M. K. Awad, "Dual emission of chalconeanalogue dyes emitting in the red region," Chemical Physics, vol. 303, no. 3, pp. 317-326, 2004.

[16] P. Rajakumar and S. Raja, "Synthesis, optical and thermal studies of dendritic architectures with chalcone surface groups," Tetrahedron Letters, vol. 49, no. 46, pp. 6539-6542, 2008.

[17] A. D’Aléo, D. Gachet, V. Heresanu, M. Giorgi, and F. Fages, "Efficient NIR-light emission from solid-state complexes of boron difluoride with $2^{\prime}$-hydroxychalcone derivatives," Chemistry-A European Journal, vol. 18, no. 40, pp. 12764-12772, 2012.

[18] N. Sirisha, R. Raghunathan, R. Jegadeesh, and N. Raaman, "Synthesis and biological activity study of some new substituted dispiropyrrolidines," International Journal Research Pharmaceutical and Bioscience, vol. 3, no. 2, pp. 28-34, 2013.

[19] E. Winter, P. D. Neuenfeldt, L. D. Chiaradia-Delatorre et al., "Symmetric bis-chalcones as a new type of breast cancer resistance protein inhibitors with a mechanism different from that of chromones," Journal of Medicinal Chemistry, vol. 57, no. 7, pp. 2930-2941, 2014.

[20] J. R. Dimmock, N. M. Kandepu, M. Hetherington et al., "Cytotoxic activities of Mannich bases of chalcones and related compounds," Journal of Medicinal Chemistry, vol. 41, no. 7, pp. 10141026, 1998.

[21] N. El-Rayyes and A.-J. A. Al-Johary, "Heterocycles. 7. Synthesis of new pyrazolines," Journal of Chemical and Engineering Data, vol. 30, no. 4, pp. 500-502, 1985.

[22] A. M. Abdel-Fattah and M. M. Elsayed, "Novel synthesis, reactions and anti-cancer activities of 4,4'-Benzene-1,4-diylbis(6phenyl-2-thioxo-1,2-dihydropyridine-3-carbonitrile)," Current Organic Chemistry, vol. 13, no. 17, pp. 1751-1757, 2009.

[23] F. Chen, F.-M. Liu, and Z.-Q. Dong, "Study of 1,3-dipolar cycloaddition and ring contraction of new 1,4-phenylenebis[1,5]benzothiazepine derivatives," Journal of Heterocyclic Chemistry, vol. 51, no. 6, pp. 1764-1769, 2014.

[24] J. L. Jat, S. Ojha, D. Bhambi, N. Dhakar, and G. L. Talesara, "Synthesis and characterization of biologically significant 5,5/-(1,4-phenylene)bis(1-N-alkoxyphthalimido-3-aryl-2pyrazoline) derivatives," Journal of Enzyme Inhibition and Medicinal Chemistry, vol. 23, no. 6, pp. 882-887, 2008.

[25] R. Gaur and L. Mishra, "Bi-nuclear Ru(II) complexes of bischalcone and bis-flavonol: synthesis, characterization, photo cleavage of DNA and Topoisomerase I inhibition," RSC Advances, vol. 3, no. 30, pp. 12210-12219, 2013.

[26] G. A. Crosby and J. N. Demas, "Measurement of photoluminescence quantum yields," Journal of Physical Chemistry, vol. 75, no. 8, pp. 991-1024, 1971.

[27] G. A. Reynolds and K. H. Drexhage, "New coumarin dyes with rigidized structure for flashlamp-pumped dye lasers," Optics Communications, vol. 13, no. 3, pp. 222-225, 1975.

[28] Siemens SMART \& SAINT, Siemens analytical X-ray instruments Inc, Madison, Wis, USA, 1996.

[29] G. M. Sheldrick, SHELXL-97 and SHELXS-97, University of Göttingen, Göttingen, Germany, 1997.

[30] D. C. G. A. Pinto, A. M. S. Silva, J. A. S. Cavaleiro, and J. Elguero, "New bis(chalcones) and their transformation into bis(pyrazoline) and bis(pyrazole) derivatives," European Journal of Organic Chemistry, no. 4, pp. 747-755, 2003. 
[31] J. R. Dyer, Applications of Absorption Spectroscopy of Organic Compounds, Prentice-Hall, New Delhi, India, 1971.

[32] F. H. Allen, O. Kennard, D. G. Watson, L. Brammer, A. G. Orpen, and R. Taylor, "Tables of bond lengths determined by $X$-ray and neutron diffraction. Part 1 . Bond lengths in organic compounds," Journal of the Chemical Society, Perkin Transactions 2, no. 12, pp. S1-S19, 1987.

[33] M. G. Tay, Z. Ngaini, M. A. M. Arif et al., "Complexation of bis-2-(benzylideneamino)phenol to cobalt(II) and zinc(II), and their spectroscopic studies," Borneo Journal of Resource Science and Technology, vol. 3, no. 1, pp. 26-34, 2013. 

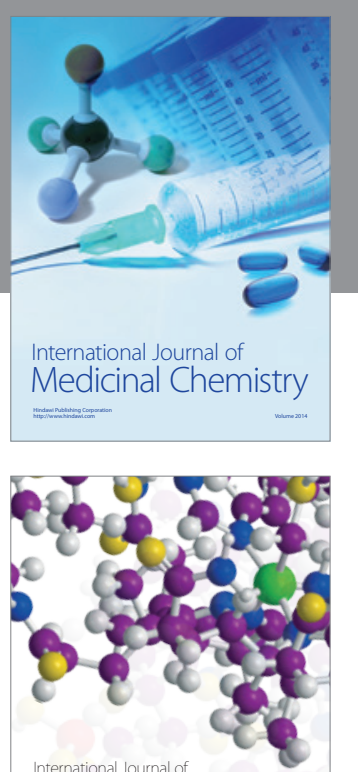

Carbohydrate Chemistry

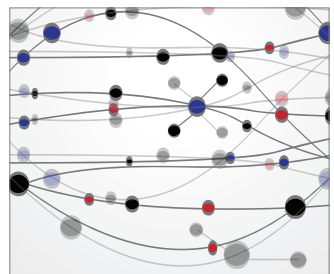

The Scientific World Journal
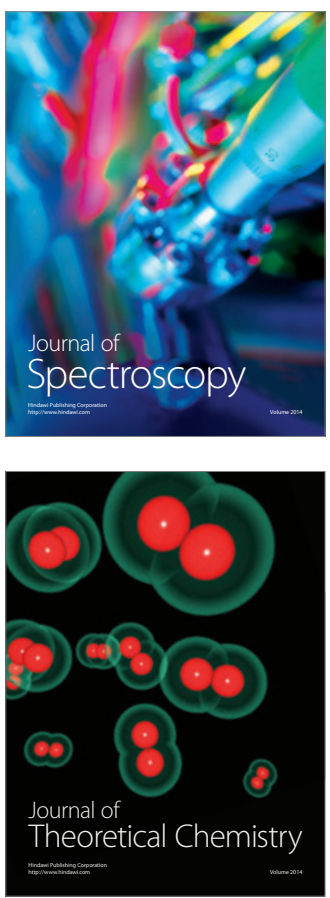
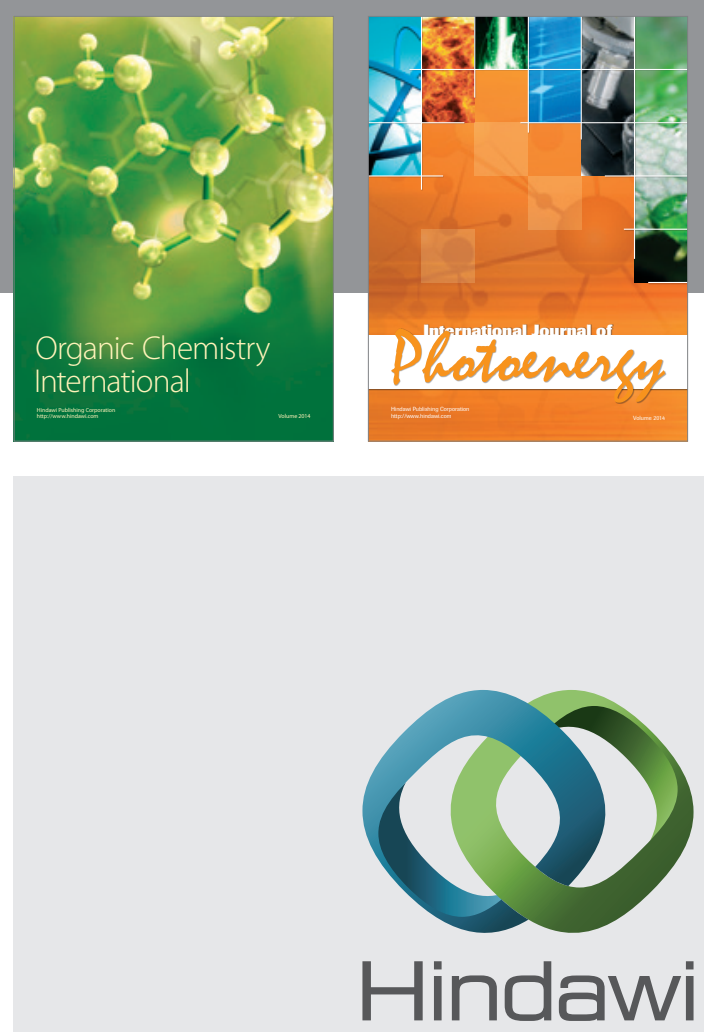

Submit your manuscripts at

http://www.hindawi.com

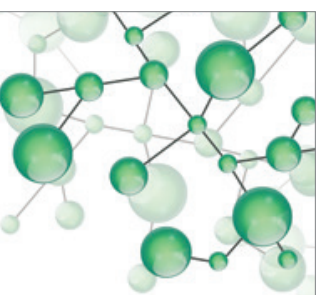

International Journal of

Inorganic Chemistry

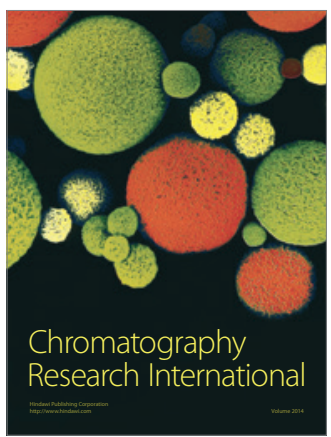

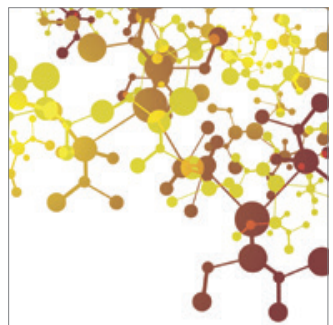

Applied Chemistry
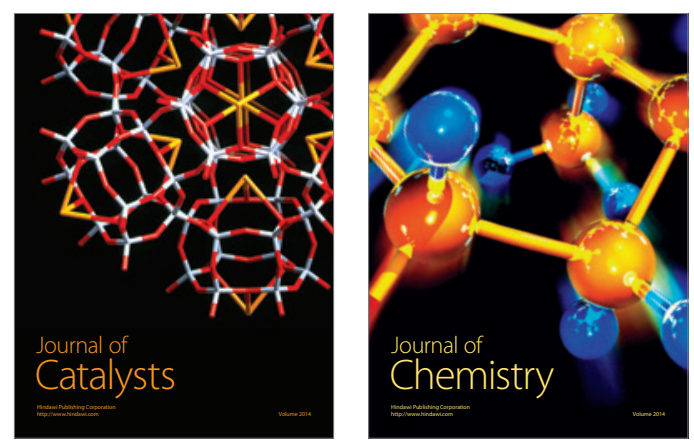
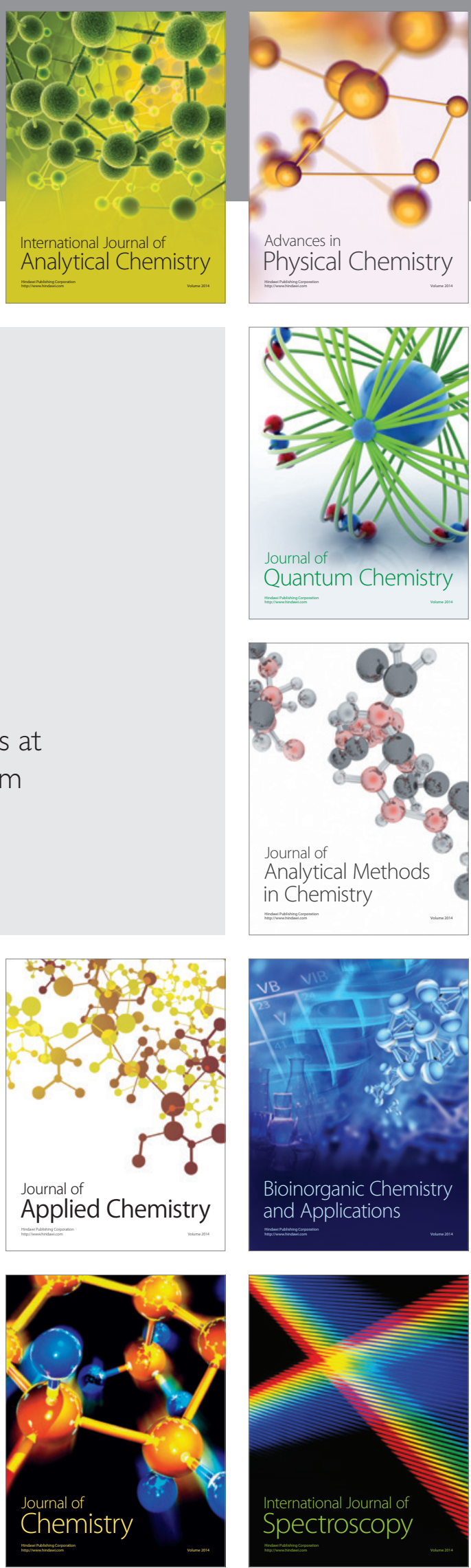